\title{
Cervus elaphus Horn Oil
}

National Cancer Institute

\section{Source}

National Cancer Institute. Cervus elaphus Horn Oil. NCI Thesaurus. Code C107283.

An extract obtained from deer antler velvet. Deer antler extract contains insulin-like growth factor-1, estrone and estradiol. It is used for its growth hormone activities and is considered a performance-enhancing drug. 